\title{
Nigerian Power Sector: A new structure required for effective and adequate power generation, transmission and distribution
}

\author{
Ebigenibo Genuine Saturday * \\ Department of Mechanical Engineering, University of Port Harcourt, Nigeria \\ Global Journal of Engineering and Technology Advances, 2021, 07(01), 006-018 \\ Publication history: Received on 25 February 2021; revised on 30 March 2021; accepted on 03 April 2021
}

Article DOI: https://doi.org/10.30574/gjeta.2021.7.1.0035

\begin{abstract}
In this paper, the structure of the Nigerian power sector is examined, the problems in the structure are identified and a new structure is proposed for effective power generation, transmission and distribution. Besides the problems usually canvassed, the current structure is defective from the perspective of the ownership of the power infrastructures, passive involvement of state governments and undue influence of the federal government. The reforms in the sector were driven by the Electric Power Sector Reform Act (EPSRA) of 2005, leading to the creation of Power Holding Company of Nigeria (PHCN) to take both the assets and the liabilities of the then National Electric Power Authority (NEPA), and the subsequent unbundling of PHCN to 18 successor companies - 6 power generating companies, one power transmission company and 11 power distribution companies. The new structure proposed in this work gives room for every state government to own power plants and distribute power in the various states. They can equally buy power from independent power producers. Power plants owned by the federal government in the present structure are to continue sending power to the national grid and made available to states with insufficient power generation in the new structure. Independent power producers can also send power to the national grid. The federal government will continue managing power transmission in the new structure. Each state government will own at least two power distribution companies in partnership with private organizations who will equally have a stake in the ownership of the power generating plants. The tariff of grid-connected power will be higher, encouraging states to go into active power generation. The new structure will enable the federal government to do away with rural electrification programme and other power generation options regulated by the Nigerian Electricity Regulatory Commission which should be under the control of various state governments. New laws are needed in the place of the EPSRA to achieve the new structure. The federal government will make money from the proposed structure instead of spending huge sums of money in the present structure.
\end{abstract}

Keywords: New structure; Power sector; Power generation; Grid-connected power; Tariff

\section{Introduction}

Every nation needs electric power to function adequately. There are several ways of generating electricity. This can be put into two major categories- conventional power generation and non-conventional power generation. In some cases, power generation options can be categorized as renewable and non-renewable. In Nigeria, all grid-connected power are conventional power plants, basically, gas turbine-based power plants and hydropower plants. Power generation in Nigeria started in 1886 with the installation of two generating sets, providing 60 kilowatts of electricity to serve the then colony of Lagos. The Electricity Corporation of Nigeria (ECN) was established by an Act of Parliament in 1951 to generate and supply electricity in Nigeria, while the Niger Dams Authority (NDA), a statutory organization, was formed in 1962 with the aim of building and maintaining dams along the River Niger and River Kaduna. The two organizationsthe ECN and the NDA, were merged in 1972 to form the then National Electric Power Authority (NEPA) [1]. NEPA was

\footnotetext{
${ }^{*}$ Corresponding author: Ebigenibo Genuine Saturday

Department of Mechanical Engineering, University of Port Harcourt, Nigeria. 
a public monopoly and was solely responsible for power generation, transmission and distribution for so long that since after its unbundling in 2005, people still call NEPA whenever electricity issues are mentioned. The Nigerian government came up with the Electric Power Sector Reform Act (EPSRA) of 2005 which made provision for the establishment of a company, Power Holding Company of Nigeria (PHCN), to take over the assets and the liabilities of NEPA as a first step [2]. Many viewed this first step as merely a change of name from NEPA to PHCN. The Nigerian Electricity Liability Management Company (NELMCO) was established to take care of some of the assets and liabilities (including pensions of employees) of PHCN. As part of the reforms, PHCN was further unbundled to 18 successor companies. This gave rise to three distinct bodies - 6 power generating companies (GenCos), a power transmission company-the Transmission Company of Nigeria (TCN) and 11 power distribution companies (DisCos) [3]. The reforms led to private participation in the power sector. 25 grid connected power plants with installed capacity of 12,522 MW was reported but the available capacity is far less while the maximum generation recorded is a little above $5000 \mathrm{MW}$ [3]. The numbers of power plants have been increasing mainly due to power stations built by state governments and private organizations. All the GenCos are meant to be privatized, the DisCos are all privatized while the TCN is owned by the Federal government. A regulatory body, Nigerian Electricity Regulatory Commission (NERC) was given birth to through the reforms. In addition to NERC, rural electrification agency (REA) and rural electrification fund (REF) were formed, where the REF is under the control of the REA. The REA is meant for providing electricity to areas far from the national grid through mini grids [2].

There are several other players in the power sector aside the power generating companies, the TCN and the DisCos. Figure 1 shows the structure of the power sector, showing some key players in the sector.

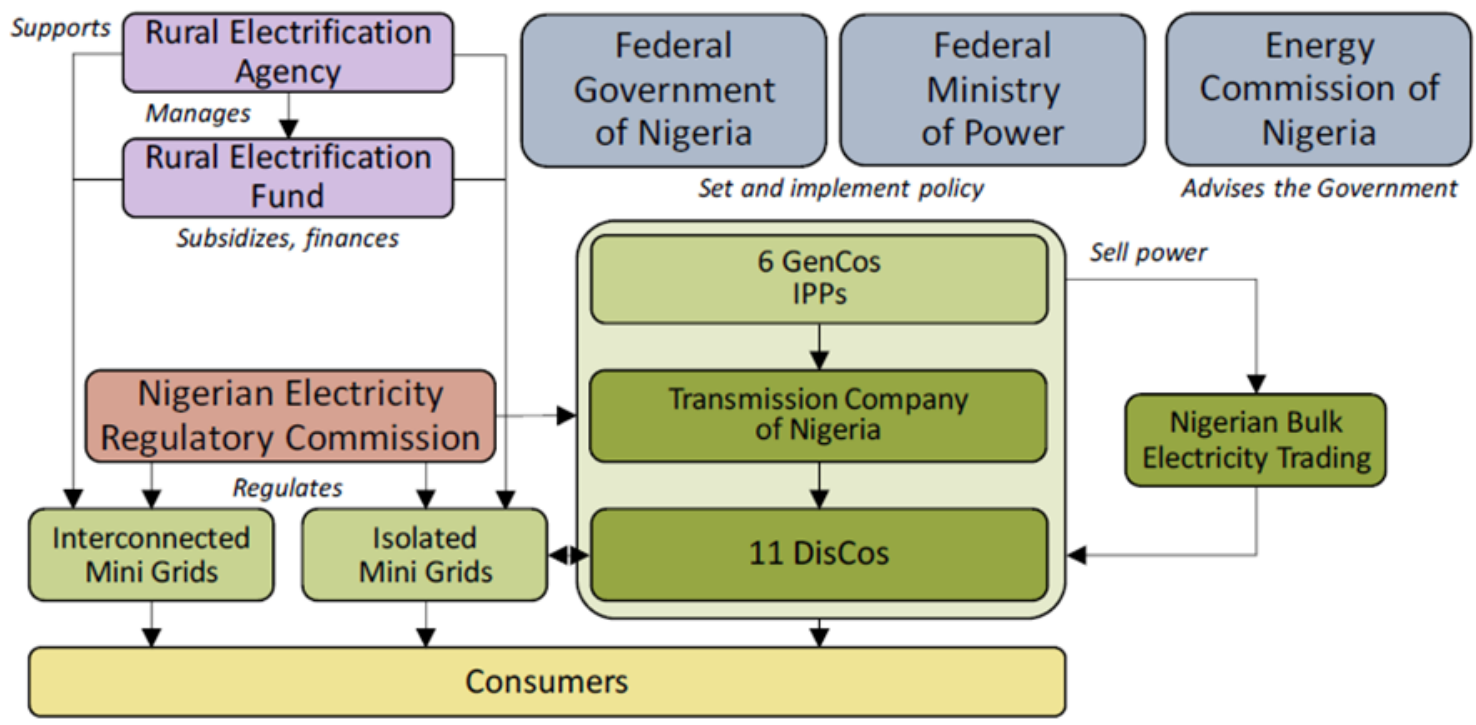

Figure 1 The structure of Nigeria power sector [4]

There are two broad parts with respect to power generation from Figure 1- power connected to the national grid and power distributed through mini grids. The ownerships of the power generating companies are different from those of the DisCos that distribute power to the consumers. Thus, grid connected power is sold by the generating companies to the DisCos through the Nigerian Bulk Electricity Trading Plc. The power is transmitted from the point of generation to various distribution substations of the DisCos by the TCN. This arrangement alone is enough to cause ineffective utilization of generated power if the DisCos are not able to handle all the power sent to them. This had been the case as many DisCos do not have sufficient infrastructure to distribute all the power sent not them. Undistributed power is as good as lost and the GenCos / the government were bearing the brunt, while the masses suffer black-out. Recently, the DisCos had been warned not to reject any power sent to them; they will pay for are the power transmitted to them whether they distribute it or not. That may not solve the problem of power supply. It is unlikely for the DisCos to improve their infrastructure within a short while to distribute all the power they receive. The DisCos' payment for undistributed power will in no way satisfy the power needs of the consumers. This is one of the major problems in the power sector aside the insufficient installed power. 
A bold step taken by the Federal government in the past decade towards increasing installed power is the national integrated power project (NIPP), under the management of Niger Delta Power Holding Company [5]. This has not been rigorously followed by further power installations. The non-availability / inadequacy of installed power had led the government into different electricity programmes such as the Energizing Economies Initiative (EEI) in 2017 for producing sustainable power for business clusters and Energizing Education Programme (EEP) for producing power for the 37 Federal Universities and Teaching Hospitals [6, 7]. These and many other programmes would not have been needed if a proper power structure was in place and enough power was generated at various locations and properly transmitted and distributed.

There are several works bordering on the review of the Nigerian power sector. Oseni [8] carried out an analysis of the performance of the power sector and concluded that the sector was underperforming. The study identified the problems in the power sector to include obsolete equipment, inadequate generation and transmission capacities stemming from decades of neglect, mismanagement and underfunding. Although, his study was done in 2011 when the NIPPs were under construction, the story is not different today as power supply remains inadequate, existing plants operating far below installed capacities, inadequate transmission infrastructure and failure of DisCos to evacuate all generated power amidst many other challenges. Okoro and Chikuni [9] reviewed the reforms in the power sector and pointed out the opportunities and the challenges in the sector. They classified the challenges into four broad categories- economic and social, technical, political and environmental. They identified the opportunities in the reforms to include improved efficiency and reliability of services, availability of employment and investment opportunities, transfer of technical manpower and research opportunities. They argued that the reforms will lead to positive competition, similar to that witnessed in the telecommunication industry. Thirteen years after the publication of their work, the power sector is yet to witness any form of meaningful improvement. An appraisal of the unresolved issues in the Nigerian power sector was carried out by Samuel et al. [10]. They identified some of the issues to be technical challenges, social-economical challenges, and political challenges. They recommended complete privatization in the sector, effective regulation in the sector by NERC and resolving billing problems as some of the solutions to the problems in the reformed power sector.

Other reviews about the power sector in Nigeria centered on the challenges in the sector after the reforms, the implications of the reforms and the solutions to the problems in the sector [11-13]. The challenges identified are not far from those enumerated in [10]. Due to the low wheeling capacity of the transmission network, off-grid power generation is often advocated as one of the solutions to inadequate power supply in the nation. Aside inadequate infrastructures at the generation, transmission and distribution levels, inadequate gas supply, breakdowns, and pricing issues / tariffs are some of the challenges often pointed out. Another drawback pointed out about the sector is that the TCN is in the hands of the Federal government and that the inefficiencies in typical corporations in Nigeria may be found in the TCN [14]. Researchers actually overlook the current structure as a problem. The current structure presented in Figure 1 poses a major problem. Different ownerships of the GenCos, the TCN and the DisCos without proper coordination and regulation is problematic. For instance, the DisCos were at liberty to reject excess power their equipment could not handle. What is the fate of the GenCos whose power plants run on natural gas that must be bought from gas producing companies? In this paper, the various aspects of the Nigerian power sector are presented. The various key players in the sector are also highlighted. More reasons why the present power structure is defective are adduced. Finally, a new structure that will enable smooth production of adequate power to meet the electricity demand of the nation is proposed.

\section{Power Generation in Nigeria}

Considering power connected to the grid, the Nigerian power industry is made of up many gas turbine power stations and three hydro power stations. Prior to the reforms, the three hydro power stations were there together with a number of gas power stations, some owned by state governments and private organizations. The power plants owned by state governments and private organizations are referred to as Independent Power Projects (IPPs). A number of new IPPs are under construction as the government through NERC has issued several licences for new IPPs. The other power stations, 7 in all (although Kainji and Jebba hydro power plants are combined to form Kainji/Jebba Hydro Electric Plc, hence usually referred to as 6 GenCos), which were existing before the reforms were owned by the Federal Government. In 2004, which is prior to the reforms, the Federal government conceived the National Integrated Power Projects (NIPP) where 7 gas turbine power stations were planned to be built. Actual funding for the NIPPs started in 2005 by the three tiers of government via the Excess Crude saving Account (ECSA). Ten (10) gas turbine based power stations were finally funded through the NIPP, where transmission as well as gas supply components are included, hence, the name integrated. The NIPPs are managed by the Niger Delta Power Holding Company (NDPHC), a limited liability company incorporated by the Federal government in 2005 [15]. Tables 1 to 3 give details of the various power plants under the GenCos existing prior to the reforms, the IPPs and the NIPPs respectively. More information about the NIPPs is provided as against the other power stations. Some of the IPPs in table 2 were previously solely owned by the federal government, 
but now privatized. It is worthy of note that the federal government has left grid-based power generation for the states and private organizations, allowing NDPHC to manage the NIPPs.

Table 1 Power generating stations prior to the reforms $[16,17,18]$

\begin{tabular}{|c|c|c|c|c|}
\hline$S / N$ & $\begin{array}{l}\text { Generating Company (Power } \\
\text { Station) }\end{array}$ & State & $\begin{array}{l}\text { Installed Capacity } \\
\text { (MW) }\end{array}$ & Type / Description \\
\hline 1 & $\begin{array}{l}\text { Afam Power Plc (Afam IV-V Power } \\
\text { Station) }\end{array}$ & Rivers & 726 & SCGTs \\
\hline 2 & $\begin{array}{l}\text { Sapele Power Plc (Sapele Power } \\
\text { Station) }\end{array}$ & Delta & 1020 & $\begin{array}{l}\text { Gas-fired steam } \\
\text { turbines and SCGTs }\end{array}$ \\
\hline 3 & $\begin{array}{l}\text { Egbin Power Plc. (Egbin Power } \\
\text { Station) }\end{array}$ & Lagos & 1320 & $\begin{array}{l}\text { Gas (Gas-fired Steam } \\
\text { turbines, six } \\
220 \mathrm{MW} \text { units) }\end{array}$ \\
\hline 4 & $\begin{array}{l}\text { Ughelli Power Plc (Transcorp } \\
\text { Ughelli Power Station) }\end{array}$ & Delta & 900 & Gas (SCGTs) \\
\hline 5 & $\begin{array}{l}\text { Kainji/Jebba Hydro Electric Plc } \\
\text { (Kainji power station) }\end{array}$ & Niger & 760 & Hydro \\
\hline 6 & $\begin{array}{l}\text { Kainji/Jebba Hydro Electric Plc } \\
\text { (Jebba Power Station) }\end{array}$ & Niger & 578 & Hydro \\
\hline 7 & $\begin{array}{l}\text { Shiroro Power Plc (Shiroro Power } \\
\text { station) }\end{array}$ & Niger & 600 & Hydro \\
\hline
\end{tabular}

SCGTs = Simple Cycle Gas Turbines

Table 2 Independent power plants (IPPs) connected to the national grid $[16,17]$

\begin{tabular}{|l|l|l|l|l|}
\hline S/N & Power Station & Location / State & Installed Capacity, MW & Type \\
\hline 1 & Okpai Power Station & Kwale, Delta & 480 & CCGT \\
\hline 2 & Afam VI Power Station & Afam, Rivers & 624 & CCGT \\
\hline 3 & AES Barge & Egbin, Lagos & 270 & SCGTs \\
\hline 4 & Trans-Amadi Power Station & Port Harcourt, Rivers & 136 & SCGTs \\
\hline 5 & Omoku Power Station & Omoku, Rivers & 150 & SCGTs \\
\hline 6 & Aba Power Station & Aba, Abia & 140 & SCGTs \\
\hline 7 & Ibom Power Station & Ikot Abasi, Akwa Ibom & 190 & SCGTs \\
\hline 8 & Rivers IPP & Afam, Rivers & 180 & SCGTs \\
\hline 9 & Geregu I Power Station & Geregu, Kogi & 414 & SCGTs \\
\hline 11 & Omotosho I Power Station & Omotosho, Ondo & 336 & SCGTs \\
\hline 12 & Olorunsogo I Power Station & Olorunsogo, Ogun & 336 & SCGTs \\
\hline 13. & Azura Power Station & Benin city, Edo & 450 & SCGTs \\
\hline
\end{tabular}


Table 3 Power Plants in the National Integrated Power Project [15].

\begin{tabular}{|c|c|c|c|c|c|}
\hline \multirow[t]{2}{*}{$\mathbf{S} / \mathbf{N}$} & \multirow[t]{2}{*}{ Power Station } & \multirow[t]{2}{*}{ Location / State } & \multicolumn{2}{|c|}{$\begin{array}{l}\text { Installed Capacity, } \\
\text { MW }\end{array}$} & \multirow[t]{2}{*}{ Description } \\
\hline & & & ISO & Net Value & \\
\hline 1 & Olorunsogo II PP & Olorunsogo, Ogun & 754 & 676 & CCGT, 4 GTs and 2 STs \\
\hline 2 & Geregu II PP & Ajaokuta, Kogi & 506.1 & 434 & SCGTs, to be converted to CCGT \\
\hline 3 & Gbarain PP & Gbarain, Bayelsa & 253.8 & 225 & SCGTs, to be converted to CCGT \\
\hline 4 & Ihovbor PP & Benin city, Edo & 507.6 & 451 & SCGTs, to be converted to CCGT \\
\hline 5 & Alaoji PP & Alaoji, Abia & 1076 & - & CCGT, 4 GTs and 2 STs \\
\hline 6 & Omoku II PP & Omoku, Rivers & 264.7 & 225 & SCGTs, to be converted to CCGT \\
\hline 7 & Egbema II PP & Egbema, Imo & 380.7 & 338 & SCGTs, 3 GTs \\
\hline 8 & Sapele II PP & Sapele, Delta & 507.6 & 451 & SCGTs, 4 GTs \\
\hline 9 & Omotosho II PP & Okotipupa, Ondo & 512.8 & 451 & SCGTs, to be converted to CCGT \\
\hline 10 & $\begin{array}{ll}\text { Calabar II } & \text { PP } \\
\text { (Odukpani PP) } & \end{array}$ & $\begin{array}{l}\text { Calabar, } \quad \text { Cross } \\
\text { River }\end{array}$ & 634.5 & 562 & SCGTs, to be converted to CCGT \\
\hline
\end{tabular}

While all the gas power stations in Table 1 are completely sold (except Sapele power Plc that is $51 \%$ sold), all the hydro power stations have been put into long term concession. The installed capacity of the NIPP plants are given in both International Standard Organization (ISO) condition and the net value obtainable from the field (except Alaoji power plant where only ISO value is provided) based on the operating conditions. The installed capacity of the other plants in Tables 1 and 2 are likely ISO conditions, as field values from some of these plants are far lower than those presented here. All the NIPP plants are gas turbine plants with two having combined cycle configuration and the rest with simple cycle configuration where exhaust gases are allowed to escape to the atmosphere. Like some other open cycle gas turbine plants installed in the past, 6 out of the 8 open cycle plants are meant to be converted to combined cycle plants in the future.

The total installed capacity of power from the power plants above is over 14,000 MW, although, much lower value is recorded from the field. There are a lot of other power stations which are either proposed, under construction, abandoned or non-operational for a long time now. Some are IPPs which are operational but not connected to the national grid. A number of solar and wind power projects have been undertaken or proposed. Oladipo et al [19] listed several power stations in Nigeria with total installed capacity over 25,000 MW. But some of the power stations listed are either under construction, non-operational or abandoned for now. Almost all the 36 state governments in Nigeria have been involved in the setting up of power plant or had planned to set up an independent power station in their various states, sometimes in partnership with private investors. There will thus be a considerable spread of power plants in Nigeria when all the proposed power plants are completed. The present inadequate supply of electricity has led the government into programmes such as the EEI and EEP which are attempts at power production for different categories of people. Some details of these two programmes and power provision options identified by NERC are presented in the following sub-sections

\subsection{Energizing Economies Initiative (EEI)}

The EEI programme was initiated by the Federal government of Nigeria in September 2017 to provide sustainable power for business clusters. The programme is under the REA (but targets mainly independent power production) and it is part of the governments Micro, Small, Medium Enterprise (MSMEs) programme. The objectives of the programme include providing clean and sustainable energy to business clusters and areas with high economic impact on the economy thereby promoting economic growth. Over 100,000 establishments in the various business clusters are targeted to be connected with $70 \%$ renewable energy based and some 7 million lives meant to be positively impacted. The initially identified economic clusters and the estimated power demand are 340 and 3-4 GW respectively. The programme is meant to create 2500 jobs, empower 200,000 MSMEs, provide clean and stable electricity to over 80,000 shops and reduce carbon emissions by 25,000 metric tonnes annually. The programme is in phases. The pilot phase targeted 3 markets which projects are completed. The markets are Sabon Gari Market Kano (decentralized solar 
technology), Sura Shopping Complex Lagos (connected to existing IPP) and the Ariaria Market Aba (utilizing internal combustion reciprocating engines fired with natural gas). This is followed by phase 1 which consists of 13 markets cutting across 7 states [6]. As laudable as the EEI programme may appear, it is only introduced because there is no enough power supply from the conventional power plants.

\subsection{Energizing Education Programme (EEP)}

The EEP was birthed by the Nigerian government to produce power for the 37 Federal Universities and 7 Teaching Hospitals across the nation. Aside providing electricity through renewable energy sources to power the university environment, the programme also entails existing distribution infrastructures upgrade and setting up in each target university a centre (world class) for renewable energy training. This programme is also implemented by the REA. The programme which is planned in phases like the EEI will provide $89.6 \mathrm{MW}$ of electricity for the target institutions. The first phase targets 9 universities and 1 university teaching hospital. Solar hybrid and/or gas fired captive power plants are to be deployed to provide $28.5 \mathrm{MW}$ of electricity for the selected institutions. Seven solar hybrid projects funded from the Green bond (fixed income securities for financing projects that has positive impact on the environment or reduce the negative impact on the environment) issued by the federal government of Nigeria (FGN). Some projects in phase 1 has been completed and commissioned while installation is going on in other places. Subsequent phases are to be funded through the Nigeria Electrification Project, which is FGN and World Bank / African development bank joint project. The phase 2 identified 7 universities and two teaching hospitals and all solar energy based [20]. The universities in the phase I of the programme cut across the six geo-political zones of the country and they include Obafemi Awolwo University, University of Lagos, Usmanu Danfodiyo University, Bayero University, Federal University of Petroleum Resources, Effurun, and four others. The phase II universities are 7 in number while 8 universities are captured in phase III. Although baseline studies have been undertaken concerning the phase II and phase III universities and technologies identified, actual projects have not taken place in any of the phase III universities [20, 21]. Phases I to III captured 24 universities, the phases for the remaining 13 universities are not available on the web. Like the EEI, the EEP would not have been necessary if the national grid covers everywhere and the electricity generated could go round. Grid connection has the major advantage of preventing any area from being shut out of power supply due to the failure of power generating systems in that area. This is the major setback in off-grid or isolated power generation / utilization.

\subsection{Power Production Opportunities in Nigeria}

Still pushed by the desire to provide power for the teeming masses of Nigeria, the Nigerian Electricity Regulator Commission identified seven different opportunities in power generation, some of the options off-grid [1]. These opportunities or options are highlighted below:

- $\quad$ Captive generation- power produced and consumed by generating entity. Operated off-grid.

- Embedded generation- Power produced in a given area connected directly to a distribution network. No need for transmission. Suitable for the EEI programme,

- Independent power producer (IPP) Off-grid- Power produced by IPP and operated off-grid. Can feature in the EEI programme. Suitable for estates, business clusters, etc.

- IPP Om-grid- Power produced by an IPP and connected to the national grid.

- Embedded Independent Electricity Distribution Network (IEDN) - Power produced in an area with no distribution network. There is possibility for connecting to existing DisCo for distribution. It can also come in the form of mapping out certain areas with willing customers (ring fencing) for power supply.

- $\quad$ Rural Off-grid IEDN - IEDN applicable to rural areas with no distribution network.

- Urban Off-Grid IEDN - IEDN applied to urban areas not connected to any transmission network.

Clearly, the FGN cannot generate, transmit and distribute power to cover every part of the nation. This led to the reforms leading to private bodies' involvement in generation and distribution. But everything still seems centralized with the nature of the controls from the NERC.

\section{Power Transmissions in Nigeria}

Power connected to the national grid is transmitted to different distribution substations for step down and distribution. Power transmission is handled by the transmission company of Nigeria, one of the products of unbundling of PHCN. The TCN is being managed by a private company, Manitoba Hydro International. The TCN is made up of three departments. They are the Transmission Service Provider (TSP) which is in charge of the maintenance of the transmission infrastructure, System Operations (SO) which oversees the flow of electricity from the point of generation to the DisCos 
and the Market Operations (MO) who are in charge of administering the market rules of the electricity supply industry [22].

A theoretical transmission wheeling capacity of $7500 \mathrm{MW}$ was reported in the past by NERC [22], while targeted values for July 2020 and year 2022 were 10,000 MW and 20,000 MW respectively [23]. The actual transmission wheeling capacity is around $5500 \mathrm{MW}$ while the grid connected power stations could generate above $8000 \mathrm{MW}$ but they are constrained to produce lower quantity of power because of the low transmission wheeling capacity [24]. The transmission wheeling capacity needs to be increased. Although, power transmission is under the FGN, there are provisions for private sector investments [22]. There are a lot of transmission projects going on now, including those of some of the NIPPs. The completion of the existing projects will not take the transmission wheeling capacity to 20,000 MW as projected for 2022 and the 10,000 MW projected in 2020 was never achieved. There are a lot of losses in the transmission network. The losses in the transmission network, cost of power transmission and difficulties in expanding the transmission network are the major reasons for the call for off-grid power generation. Off-grid power generation is an insufficient solution to the inadequate transmission network. A structural problem exists in the system and that is addressed in this work.

\section{Power Distribution in Nigeria}

Electricity can be generated and distributed from the generation point. It can equally be transmitted to far distances before being distributed. In the case of Nigeria, the power plants connected to the national grid supply electricity to the grid for transmission to various parts of the transmission network for distribution. The power sector reforms gave birth to 11 distribution companies; public limited companies serving different parts of the nation. Table 4 shows the 11 DisCos, the states/areas they cover and the percentage electricity allotted to them from the national grid by NERC.

Table 4 The eleven distribution companies [3, 25]

\begin{tabular}{|l|l|l|}
\hline Distribution company & Areas covered & $\begin{array}{l}\text { Percentage of electricity } \\
\text { allotted (\%) [3] }\end{array}$ \\
\hline $\begin{array}{l}\text { Abuja Electricity Distribution } \\
\text { Company Plc }\end{array}$ & FCT, Niger, Kogi, and Nassarawa & 12 \\
\hline $\begin{array}{l}\text { Benin Electricity Distribution } \\
\text { Company Plc }\end{array}$ & Edo, Delta, Ondo, and part of Ekiti, & 15 \\
\hline $\begin{array}{l}\text { Eko Electricity Distribution } \\
\text { Company Plc }\end{array}$ & $\begin{array}{l}\text { Southern Lagos State, Apapa, Lekki } \\
\text { Lagos Island \& part of Ogun State }\end{array}$ & 13 \\
\hline $\begin{array}{l}\text { Enugu Electricity Distribution } \\
\text { Company Plc }\end{array}$ & $\begin{array}{l}\text { Enugu, Abia, Imo Anambra and } \\
\text { Ebonyi }\end{array}$ & 9 \\
\hline $\begin{array}{l}\text { Ibadan Electricity Distribution } \\
\text { Company Plc }\end{array}$ & $\begin{array}{l}\text { Oyo, Ogun, Osun, Kwara and part of } \\
\text { Ekiti }\end{array}$ & 9 \\
\hline $\begin{array}{l}\text { Ikeja Electricity Distribution } \\
\text { Company Plc }\end{array}$ & $\begin{array}{l}\text { Lagos state - Abule Egba, Akowonjo, } \\
\text { Ikeja, Ikorodu, Oshodi, Shomolu }\end{array}$ & 11 \\
\hline $\begin{array}{l}\text { Jos Electricity Distribution } \\
\text { Company Plc }\end{array}$ & Plateau, Bauchi, Benue and Gombe & 8 \\
\hline $\begin{array}{l}\text { Kano Electricity Distribution } \\
\text { Company Plc }\end{array}$ & Kano, Jigawa and Katsina & 7 \\
\hline $\begin{array}{l}\text { Kaduna Electricity } \\
\text { Distribution Company }\end{array}$ & Kaduna,Sokoto, Kebbi and Zamfara & 6 \\
\hline $\begin{array}{l}\text { Port Harcourt Electricity } \\
\text { Distribution Company Plc }\end{array}$ & $\begin{array}{l}\text { Rivers, Cross River, Bayelsa and Akwa } \\
\text { Ibom }\end{array}$ & 8 \\
\hline $\begin{array}{l}\text { Yola Electricity Distribution } \\
\text { Company Plc }\end{array}$ & Adamawa, Borno, Taraba and Yobe & 4 \\
\hline
\end{tabular}


The percentages electricity allocation obtained from Reference [3] were rounded up and $102 \%$ instead of $100 \%$ is obtained for the total electricity. The values are thus not exact but a close representation of the actual values. The amount of electricity sent to the different DisCos in practice is a bit different from the planned percentages. The DisCos are the closest to the customers in the electricity sector. They are supposed to provide meters for every customer, connect new customers to their network and collect electricity tariff from customers. How much they default in their duties is traceable to a structural problem identified later in this work.

\section{Key Players in the Nigerian Power Sector}

Aside the GenCos and their owners, the TCN, the DisCOs and NERC, there are several other key players in the power sector which functions need to be pointed out. They include the following:

- $\quad$ The Federal Ministry of Power- Make policies and provide general guidelines concerning the operations and operators in the sector.

- $\quad$ Nigeria Bulk Electricity Trading (NBET) Plc - Oversees the purchase / sales of electricity between GenCos and the DisCos. NBET was incorporated on the 29th day of July 2010; it is $100 \%$ owned by the Federal government of Nigerian.

- Private sector natural gas producers - mainly international oil companies (IOCs) and indigenous oil and gas companies. Their importance lies in the fact that they provide natural gas for the plenty gas turbine power plants in the nation.

- Nigerian National Petroleum Corporation (NNPC) and two of its subsidiaries - the Nigerian Gas Company (NGC) and the Nigerian Petroleum Development Company (NPDC) - Involved in natural gas production and tends to regulate the operations of IOCs and the indigenous oil and gas companies

- Gas Aggregation Company of Nigeria Limited (GACN) - Incorporated in Nigeria in January 5 2010, to encourage growth and utilization of natural gas. Among other functions, it manages domestic gas supply obligations between suppliers and the buyers (some GenCos in this case). The NNPC, Shell Petroleum Development Company Limited (SPDC) and four other companies are stakeholders in GACN [26]

- $\quad$ Nigerian Electricity Management Services Agency (NEMSA) - Established by an Act of the Federal government of Nigeria in 2015. It is meant to enforce technical standard and regulations, and ensure safety of all categories of electrical installations through inspection, testing and certification.

- Energy Commission of Nigeria (ECN) - The ECN was established by an Act of the Federal Government of Nigeria on $14^{\text {th }}$ September 1979 . It plays advisory role to the government concerning planning, development and utilization of energy in Nigeria.

\section{Policies and Laws Concerning the Power Sector in Nigeria}

There are a number of policies or laws; some formulated by some government agencies, which affect the power sector directly. Some of these policies and laws are presented here.

- $\quad$ Electric Power Sector Reform Act (EPSRA), 2005 - This is the act that led to the transformation of NEPA to PHCN and later the unbundling of PHCN to 6 GenCos, the TCN and 11 DisCos. NERC and REA were brought to bear through this act. The EPSRA was given birth to by a previous policy, the National Electric Power Policy (NEPP) of 2001.

- National Energy Policy (NEP) - The NEP is a brain-child of the ECN. The NEP is towards optimum utilization of the nation's diverse energy resources. First formulated in 2003, reviewed in 2013 and 2018 respectively. Electricity policy is captured in chapter 7 of the latest review [27]. As a policy document, under normal circumstances, it will guide the government in electricity generation, transmission and distribution.

- National Energy Master Plan (NEMP) - The NEMP was provided by the ECN in 2014. It is more or less an implementation plan of the contents of the NEP.

- National Renewable Energy and Energy Efficiency Policy (NREEEP) - Another brain-child of the ECN, practically extracted from the NEP in 2014. Renewable energy for electricity generation is one of the key areas in the document.

- $\quad$ Renewable Energy Master Plan (REMP) - The REMP was brought to bear by the ECN and the United Nations Development Programme (UNDP) in 2005. It is a more comprehensive and detailed document compared to the NREEP. The document provides a roadmap for increasing renewable energy usage including electricity generation through various renewable energy resources.

- Renewable Energy Policy Guidelines (REPG) - Developed by the Federal government through the Ministry of Power and Steel in 2006. It provides guidelines for promoting electricity generation through renewable energy. 


\section{Major Problems in the Power Sector/ Basic Flaws in the Reforms}

Aside the technical, social-economic, political and environmental challenges pointed out by previous researchers in the reformed power sector, the current structure is actually defective. The major defects are presented here.

\subsection{Ownership Structure}

The first defect is the ownerships of the GenCos, the TCN and the DisCos. All the DisCos are now privately owned, while the Federal government and some state governments have much stake in some of the GenCos. The TCN is purely in the hands of the FGN. The DisCos buy power from the GenCos through the NBET and sell to the customers. The DisCos do reject the power provided by the GenCos based on the capacity of their infrastructures. They have not been able to expand and upgrade their infrastructure to accept and distribute the additional power from the increasing power installations across the nation. This scenario would have been avoided if the GenCos and the DisCos were co-ownedyou will endeavour to distribute all the power you generated. Although the DisCos have been recently warned to pay for any power they reject, it is difficult to tell if that treat will lead to rapid upgrading in infrastructures of the DisCos and effective power distribution.

\subsection{Absence of State Governments in the Regulatory Structure}

Apart from Eko and Ikeja DisCos, all other DisCos supply power to a number of states and their operations are being regulated by NERC which is under the federal government. State governments who are desirous of providing power for their states are mandated to provide power plants as IPPs and sell power to same ineffective DisCos through the NBET or provide power through the interconnected mini grid and isolated mini grid options which are still under the control of the NERC. State governments who have the means of providing power for their states are thus 'handicapped' with the existing structure. For instance, the awkwardness of the NBET comes to bear when a state government build a power plant and tends to supply it to its territory- NBET will step in and inform the state government that they are in charge of buying electricity from the GenCos and selling same to the DisCos. A similar scenario reportedly occurred in Edo state when the state government completed the Azura Power Station in Benin City. This will definitely discourage state governments from investing in power generation knowing that they will not have any control and usage of the generated power unless it is coming in low packages. There is no form of competition between the different states in investing in the power sector. This is in no way exonerating the state governments in the poor power supply system witnessed in the country. This is because the current power structure and mode of implementation is a violation of the 1999 Constitution of Nigeria as amended where power is in the concurrent list. This means state governments can equally make laws on power generation, transmission and distribution within their states and operate as such. Allowing the federal government to regulate the power generation, transmission and distribution within their states can be described as deliberate attempt of the state governments to neglect their constitutional responsibility; even if it is ignorance, it is unacceptable, hence, they are culpable.

\subsection{Mode of Operation of the Rural Electrification Agency}

The rural electrification agency which is meant for providing electricity to areas far from the national grid through mini grids is an agency of the federal government. The rural areas are in the various local governments in the different states. The closest administrative unit to the rural area far from the national grid is the local government councils. The farthest points to pursue rural electrification should thus be from the different state fronts instead of the federal government the federal government should not have any business in any form of rural electrification exercise. The agency has not fared well so far. The Energizing Economies Initiative programme for providing sustainable power for business clusters is under the REA. Ironically, none of the business clusters attended to is in a rural area where the programme is originally set up for. Often, electricity through renewable energy is pursued. As beautiful as electricity through renewable energy appeals to us, the potentials from the various resources and the cost implications should be properly weighed in comparison with other energy resources. For instance, it will be uneconomical to power rural communities in Delta state or Rivers state with solar electricity considering the low solar irradiation in these states and the high cost of solar electricity in such locations going by their low capacity factors [28]. The high gas deposits in these states calls for electricity through gas turbines [23]. Solar photovoltaic systems and wind energy systems should target areas with high capacity factors. The renewable energy pursuit of the REA appears not to be conscious of these facts. The major complain has been lack of funds, and renewable energy installation for electricity production is not yet cheap. 


\section{The way forward}

The way forward is a new structure as presented in Figure 3. In the proposed structure, power generation, power transmission and power distribution are clearly presented. The power purchase process is also captured. The relevant parts in the proposed structure are briefly explained below.

\subsection{Power Generation in the Proposed Structure}

There are three different power generating companies in the proposed structure. They are power generating companies owned by the different state governments either in partnership with private organizations or not, independent power generating companies which are solely owned by private organizations and power generating companies owned by the Federal government. All these categories of power generating companies presently exist in the nation. The traditional 6 GenCos and the NIPP projects can best be termed Federal government power generating plants. They are connected to the national grid. The new structure demands that the federal government owned power plants should continue to be connected to the national grid and supply power only to those states that are not able to provide enough power to meet their local demands. The independent power plants can sell power to the various states directly or through the national grid via the NBET. Sale of power to the states directly should be done through the state power generating plants which must be co-owned- the distribution companies must have shares in the state power generating companies. Any state without power generating companies should set up a body responsible for power purchase arrangements from both the Federal government owned power plants and independent power plants. Here, also, the DisCos should be fully represented in such bodies. The structure makes provision for states with excess power supply to get power from the national grid whenever production falls below demand due to failure of power plants. In the same vein, those states with insufficient power generation can equally send excess power to the national grid in the future when their production is above the demand. These provisions are indicated with dash lines in Figure 3.

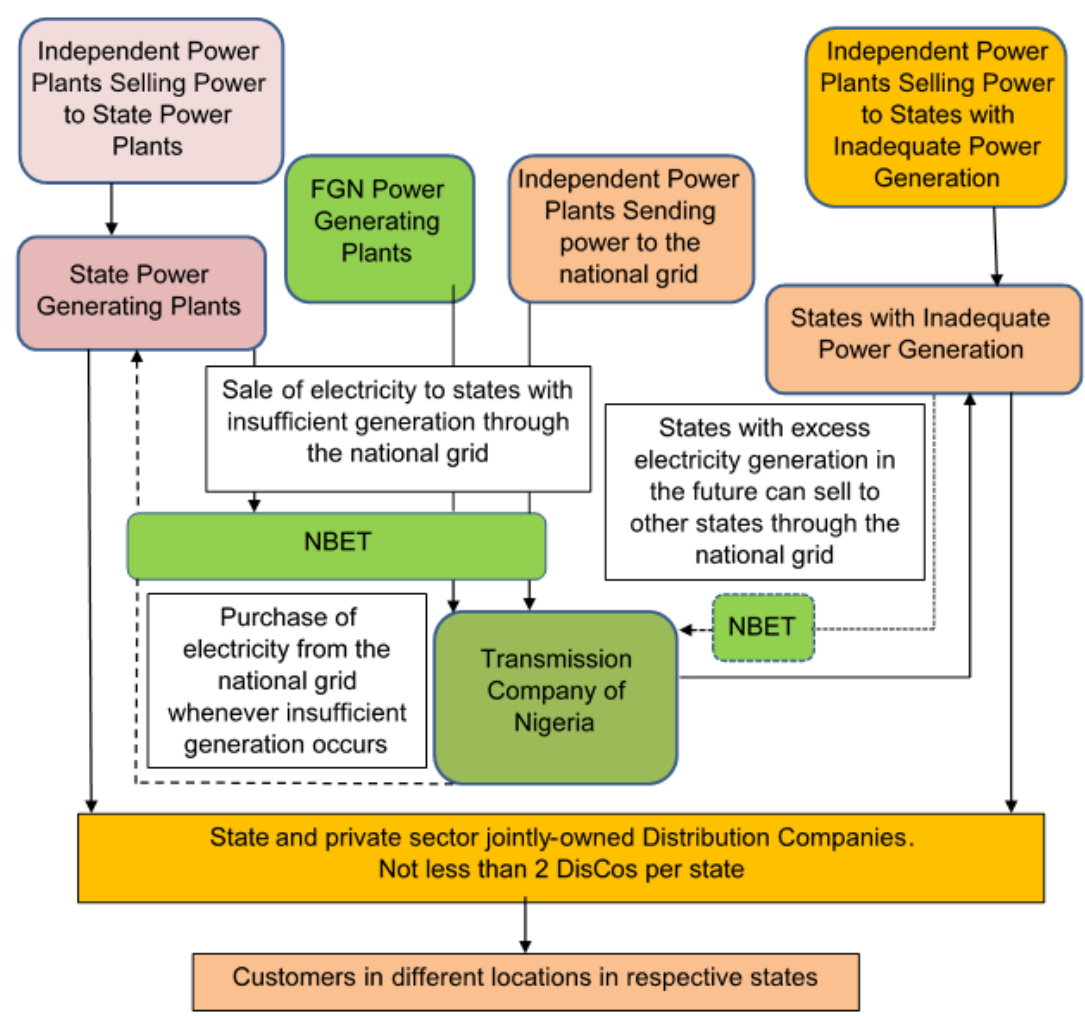

Figure 3 Proposed power structure for effective power generation, transmission and distribution.

\subsection{Power Transmission in the Proposed Structure}

Power transmission should be done through the national grid by the TCN. The federal government should ensure that the lapses in the grid are corrected. The government should complete the on-going expansion of the national grid. The grid should be upgraded to be able to have a wheeling capacity not less than the installed power capacity from the 
federal government owned power plants. There may be no need for further expansion in the nearest future since all state governments are encouraged to generate power and distribute in their respective states.

\subsection{Power Distribution in the Proposed Structure}

In the proposed structure, every state must have at least two distribution companies taking care of different parts of the respective states. The DisCos must be owned by the state governments and private organizations, such private organizations also having stakes in the power generating companies. The state governments can allow the private partners in the management of the DisCos for effective performance. They should have up to $40 \%$ shares in the respective DisCos and not less than $50 \%$ shares in the power generating companies. The private partners in each DisCo should have up to $10 \%$ shares in the power generating companies and they should be properly represented in the management of the generating companies. The implication of this proposed structure with respective to the existing DisCos implies carrying out a number of changes. First, more DisCos should come on board and the state governments should buy shares in the existing DisCos.

\subsection{Regulations, Electricity Pricing and Federal Government Involvement}

The new structure requires new laws to back the changes. The changes required may not be difficult to come by from both the technical and legal viewpoints. The EPSRA has already done a lot of good to the system in terms of breaking the monopoly of the then NEPA, formation of PHCN, unbundling of the PHCN to 18 successor companies and the privatization of the successor companies except the TCN. Where we are is thus closer to the new structure than our movement to the present position from the NEPA era. The EPSRA also gave conditions for cancelling the licences of any of the successor companies. In this regard, all the DisCos have fallen short of the provisions of the act on financial grounds. Thus, carrying out further modifications will not lead to unnecessary litigations. Credit should be given to the reforms so far. Moving forward, the functions of NERC should be modified. The seven power production opportunities in Nigeria presented in section 2.3 under NERC regulations will naturally dissolve with the proposed structure. NERC should have no involvement in any of those power generation options. The various state governments should implement any if they find the need. NBET should focus on electricity sale agreements for grid-connected electricity, whether coming from the IPPs, the state governments with excess electricity or from the federal government owned power plants. The price of electricity (electricity tariff) will definitely vary from state to state, but boundaries should be set by the NERC. Generally, grid-connected electricity will be more expensive due to transmission costs and the involvement of NBET which services must to be paid for. The Federal government should not appear like a 'Father Christmas' paying for the inefficiencies in the system. The federal government has no business paying subsidy for electricity consumption by the consumers as it is today. The federal government should be making profit from the power sector through its power plants, the TCN, electricity purchase / sales by NBET and taxes from the DisCos. The federal government through the ministry of power should focus on effective operation of the organizations managing its power plants (whether partly privatized or on long term concession), TCN, NERC and NBET. The federal government should do away with the REA and recoup funds for upgrading the TCN.

\section{Conclusion}

The problems in the reformed Nigerian power sector are identified in this work and a new structure that will facilitate effective power generation, transmission and distribution is proposed. The reforms have led to the dismantling of NEPA via PHCN to 18 companies with private sector involvement. We have power generating plants owned by the federal government that are being managed by private organizations, power plants owned by state governments and those by private organizations. Electricity transmission is handled by the federal government through the TCN. Eleven DisCos are in charge of electricity distribution across the nation but they have not been able to improve their infrastructure to take care of the additional power installations providing power to the national grid. In the proposed structure, private organizations can sell power directly to any state or through the national grid while power plants owned by the federal government are to sell power to other states through the national grid. Every state is encouraged to own power generating plants. States with excess power generation can equally send excess power to the national grid. The federal government is encouraged to improve the power transmission infrastructure and continue handling power transmission. The new structure proposed has at least two DisCos per state jointly-owned by the state government and private organizations. The private organizations in the DisCos should also have stake in the ownership of the power plants in the states. The new structure calls for new laws in the place of the EPSRA and federal government control mechanisms requires thorough modifications. The proposed structure will lead to the FGN making money from the power sector instead of paying for the inefficiencies in the present system. 


\section{Compliance with ethical standards}

\section{Acknowledgments}

The author is very grateful to the department of Mechanical Engineering, University of Port Harcourt, for providing a conducive environment for this work to be carried out.

\section{Disclosure of conflict of interest}

None.

\section{References}

[1] Nigerian Electricity Regulatory Commission [Internet]. Power generation in Nigeria, [cited 2020 December 12].

[2] Federal Government of Nigeria. Electric power sector reform act, 2005 [cited 2020 December 12].

[3] Federal Government of Nigeria. Nigeria power baseline report, 2017 [cited 2020 December 12].

[4] World Bank. Mini grids in Nigeria: a case study of a promising market, 2017 [cited 2020 December 12].

[5] Niger Delta Power Holding Company [Internet]. Company history, [cited 2020 December 12].

[6] Rural Electrification Agency [Internet]. Energizing economies initiative, [cited 2020 December 13].

[7] Energizing Education Programme [Internet]. [cited 2020 December 13].

[8] Oseni MO. An analysis of the power sector performance in Nigeria, Renewable and Sustainable Energy Reviews. 2011; 15: 4765- 4774.

[9] Okoro OI, Chikuni E. Power sector reforms in Nigeria: opportunities and challenges, Journal of Energy in Southern Africa. 2007; 18(3): 52-57.

[10] Samuel SI, Jide I, Ayo O. Nigeria's electricity power sector reform: An appraisal of unresolved issues, International Journal of Energy Economics and Policy. 2019; 9(6): 336-341.

[11] Abanihi VK, Ikheloa SO, Okodede F. Overview of the Nigerian power sector, American Journal of Engineering Research (AJER). 2018; 7(5): 253-263.

[12] Sambo AS, Garba B, Zarma IH, Gaji MM. Electricity generation and the present challenges in the Nigerian power sector, 2009 [cited 2020 December 19].

[13] Alao 0, Awodele K. An overview of the Nigerian power sector, the challenges of its national grid and off-grid development as a proposed solution, IEEE PES/IAS PowerAfrica. 2018; 178-183.

[14] Nwokoye ES, Dimnwobi SK, Ekesiobi CS, Obegolu CC. Power infrastructure and electricity in Nigeria: policy considerations for economic welfare, KIU Journal of Humanities. 2017; 2(1): 5-17.

[15] Niger Delta Power Holding Company [Internet]. Generation, [cited 2020 December 17].

[16] Nigerian Electricity Regulatory Commission [Internet].Power generation in Nigeria, [cited 2020 December 17].

[17] NERP [Internet]. Archives: power plants, [cited 2020 December 17].

[18] GET. Invest [Internet] Nigeria energy sector, [cited 2020 December 18].

[19] Oladipo K, Felix AA, Bango O, Chukwuemeka O, Olawale F. Power sector reform in Nigeria: challenges and solutions, IOP Conf. Series: Materials Science and Engineering, 2018; 413: 012037.

[20] Federal Government of Nigeria [Internet]. Fact sheet on energizing education programme, [cited 2020 December 17].

[21] Rural Electrification Agency [Internet]. Energizing Education, [cited 2020 December 17].

[22] Nigerian Electricity Regulatory Commission [Internet]. Transmission, [cited 2020 December 17].

[23] Saturday EG, Ebieto CE. Nigerian power sector: Why gas turbines will be relevant for the next 50 years, Global Journal of Engineering and Technology Advances. 2020; 5(1): 66-75. 
[24] Africa Energy Portal [Internet]. Nigeria: Gencos - 4,159MW now stranded from national grid, [cited 2020 December 27].

[25] Nigerian Electricity Regulatory Commission [Internet]. Distribution Companies (DisCos), [cited 2021 January 10].

[26] Gas Aggregation Company of Nigeria (GACN) [Internet]. GACN shareholders, [cited 2021 January 11].

[27] Energy Commission of Nigeria. National Energy Policy, [cited 2021 January 13].

[28] Saturday EG, Aderibigbe OA. The Economic implication of renewable energy utilization in Nigeria, Saudi Journal of Engineering and Technology. 2020; 5(12): 524-535. 